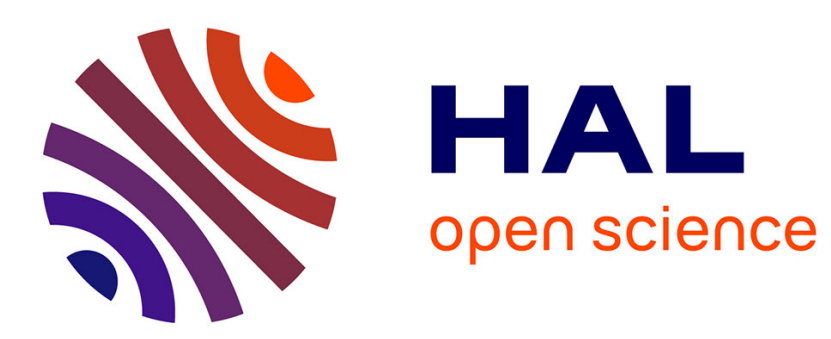

\title{
Soil compaction enhances the impact of microwave heating on seedling emergence
}

\author{
Manon C.M. Hess, Elise Buisson, François Mesléard
}

\section{To cite this version:}

Manon C.M. Hess, Elise Buisson, François Mesléard. Soil compaction enhances the impact of microwave heating on seedling emergence. Flora, 2019, 259, pp.151457. 10.1016/j.flora.2019.151457 . hal-02463272

\section{HAL Id: hal-02463272 \\ https://hal.science/hal-02463272}

Submitted on 20 Dec 2021

HAL is a multi-disciplinary open access archive for the deposit and dissemination of scientific research documents, whether they are published or not. The documents may come from teaching and research institutions in France or abroad, or from public or private research centers.
L'archive ouverte pluridisciplinaire HAL, est destinée au dépôt et à la diffusion de documents scientifiques de niveau recherche, publiés ou non, émanant des établissements d'enseignement et de recherche français ou étrangers, des laboratoires publics ou privés.

\section{다)(1) $(5$}

Distributed under a Creative Commons Attribution - NonCommercial| 4.0 International 
1 Soil compaction enhances the impact of microwave heating on seedling emergence

3 level should therefore be considered in the design of the final microwave-based process.

\section{$\underline{\text { Manon C. M. Hess }}^{1,2}$, Elise Buisson ${ }^{1}$ and François Mesléard ${ }^{1,2}$}

${ }^{1}$ Institut Méditerranéen de Biodiversité et d'Ecologie marine et continentale (IMBE), Avignon Université, UMR CNRS IRD Aix Marseille Université, IUT Site Agroparc, BP 61207, 84911 Avignon Cedex 09, France

${ }^{2}$ Institut de recherche pour la conservation des zones humides méditerranéennes Tour du Valat, Le Sambuc, 13200 Arles, France

Corresponding author: hess@ tourduvalat.org

\section{Abstract}

An innovative microwave-based process to control invasive species in the field is currently under development. We investigated the effect of soil compaction levels under three microwave treatment pairings of power and duration (2kW4min, $2 \mathrm{~kW} 8 \mathrm{~min}$ and $4 \mathrm{~kW} 4 \mathrm{~min})$, on seedling emergence of a diverse seed bank and three major invasive species in Europe (bohemian knotweed, giant goldenrod and jimsonweed). When soil was compacted, the number of seedling emergences of dicotyledons was significantly reduced by the $2 \mathrm{~kW} 4 \mathrm{~min}$ treatment. Furthermore, while some dicotyledon and giant goldenrod's seedling emergences were observed respectively in plain soil in the $4 \mathrm{~kW} 4 \mathrm{~min}$ and $2 \mathrm{~kW} 4 \mathrm{~min}$ treatments, no seedling was recorded in compacted soil for the same treatments. Our results suggest that compacting soil increases the efficiency of microwave heating on seeds. Soil compaction

27 Keywords: invasive species control; seed-bank; microwave heating 


\section{Introduction}

Successful eradication of an invasive species requires an effective depletion of the seeds and vegetative propagules, e.g. rhizomes (Myers et al., 1998; Regan et al., 2006; Saito and Tsuyuzaki, 2012). Complete destruction of invasive seed banks is rarely achieved by herbicide application (Christoffoleti et al., 2007), thus alternative methods have been developed. Biological control using natural enemies can be effective in reducing seed production or accumulation in the soil (Adair, 2005; Impson et al., 2004; Zimmermann et al., 2004), but the release of exotic biological agents has been shown to raise ecological issues like negative impacts on native biota (Strong and Pemberton, 2000). Heating methods are of interest since they provide chemical-residue-free weed control. The use of fire is appropriate to reduce upper seed banks in fire-adapted ecosystems (Holmes, 1989; Richardson and Kluge, 2008), but is not suitable for some ecosystems (i.e. wetlands and dunes) and can sterilize soil for years (Campbell et al., 1999). Soil solarization, based on solar heating of soil by mulching it with plastic sheets during the hot seasons, raises temperatures usually up to 40 to $55^{\circ} \mathrm{C}$ in the upper $5 \mathrm{~cm}$ of the soil (Cohen, 2008), enabling the reduction of invasive species seed banks (Cohen et al., 2018). This method however showed certain limitations, such as length of treatment (i.e. several months), climate-dependency, and variable effectiveness (Cohen and Rubin, 2007). Microwave soil heating has been considered for weed control for several decades (Barker and Craker, 1991; Davis et al., 1971; Sartorato et al., 2006). Microwave radiation induces dielectric heating of moist materials, enabling soil to reach temperatures required for seed viability loss (i.e. $60^{\circ} \mathrm{C}-90^{\circ} \mathrm{C}$; Brodie et al., 2011; Sahin, 2014; Thompson et al., 1997). Exposure to high temperatures can impact seed mortality directly via thermal

50 killing, or indirectly via increased susceptibility to toxic compounds and microorganisms, i.e.

51 "weakening effects" (Katan et al., 2012). In some cases, heat can break dormancy and 52 stimulate germination (i.e. seeds displaying physical dormancy; Baskin et al., 1998; Herranz 
et al., 1998; Tieu et al., 2001). Several studies revealed however a great potential for

54 microwave heating to control germination of many weed species (Bebawi et al., 2007; Brodie et al., 2009; Nelson, 1996 ; Sahin, 2014), but the microwave technology used at the time was not developed enough to draw a cost effective and marketable application (Brodie et al., 2011). This study is part of a set of studies undertaken to help determine the technical characteristics of a continuous conveying tunnel with microwave equipment, designed for the treatment of soil infested by a wide range of invasive species (seeds and adult stages) collected in situ. Infested soil, once passed through the microwave oven on a conveyor belt, can be put back in place. First studies hold promising results for seedling emergence reduction, with high effectiveness when soil temperature reached $85^{\circ} \mathrm{C}$ (De Wilde et al., 2017; Hess et al., 2018). Before this process can be implemented full scale, however, more information is needed on the parameters influencing the effectiveness of microwave treatments. Soil characteristics that mostly alter the dielectric properties of soil, such as initial temperature, texture and moisture content, have been shown to strongly influence the temperature achieved after microwave exposure (Barker and Craker, 1991; Brodie, 2011; Brodie et al., 2011; Davis et al., 1971; Davis et al., 1973; De Wilde et al., 2017). Soil compaction has so far been neglected, although compaction directly influences the dielectric properties of the soil (De Vries, 1952). Increasing soil compaction leads to higher bulk density and lower porosity, thereby enhancing thermal conductivity (Abu-Hamdeh, 2000; Yadav and Saxena, 1973). Soil compaction may consequently impact the effectiveness of microwave heating in inhibiting seedling emergence.

We investigated the influence of soil compaction on microwave heating effectiveness in inhibiting seedling emergence by comparing the seedling emergence response in plain or compacted soil during exposure to three microwave treatment pairings of power and duration. 
in situ not for its invasion status (non-invaded), but because it contained a great diversity of species. We also monitored the seedling emergence response of three emblematic invasive species in Europe (i.e. Datura stramonium L., Reynoutria $\times$ bohemica Chrtek and Chrtková and Solidago gigantea Aiton) already used in previous studies (De Wilde et al., 2017; Hess et al., 2018) by placing a fixed number of seeds in the soil before treatments were applied. Reported as highly aggressive in some European countries (Kleunen et al., 2007; Weber, 2003; Weber and Jakobs, 2004), these species were selected because they reproduce by seeds (Gillies et al., 2016; Saayman, 2000; Weber and Jakobs, 2004) and more importantly because their seeds differ in shape and size. Indeed, these characteristics are known to strongly influence seed sensitivity to microwave heating (Bebawi et al., 2007; Brodie et al., 2011). Furthermore, none of the three species' seeds displays physical dormancy (Bochenek et al., 2016; Engler et al., 2011; Loddo et al., 2013).

\section{Material and methods}

The experiment was designed to test the impact of soil compaction ('plain' vs 'compacted') during three microwave treatment pairings of power and duration $(2 \mathrm{~kW} 4 \mathrm{~min}$, $2 \mathrm{~kW} 8 \mathrm{~min}$ and $4 \mathrm{~kW} 4 \mathrm{~min}$ ) on seedling emergence of three invasive species in Europe (Datura stramonium, Reynoutria $\times$ bohemica and Solidago gigantea) and a seed bank contained in soil extracted in situ.

\subsection{Soil sampling}

Topsoil, characterized as a silty loam (60\% silt, 15\% clay), was collected from uncultivated species-rich grassland on an abandoned organic hemp growing field (production halted in 2013) located near two rivers, La Cèze and La Tave (Laudun-L'Ardoise, France). The 25 soil samples collected $(1.35 \mathrm{~m} \pm 0.15 \mathrm{~m}$ length $\times 0.5 \mathrm{~m} \pm 0.1 \mathrm{~m}$ width $\times 0.1 \mathrm{~m}$ depth $)$ were mixed to ensure relative homogeneity of soil and seed bank. Blended soil cleared of 
stones and organic residues was distributed in $1 \mathrm{~kg}$ batches just before microwave treatments were applied.

2.2 Seed sampling of the three invasive species

Achenes of Reynoutria $\times$ bohemica and Solidago gigantea were collected in March

2016 along the Isère River in Savoie (France). Seeds of Datura stramonium were collected in

October 2014 from stands growing along the Rhône River in Drôme (France). The achenes and seeds were collected randomly from ten ramets of the same population (to reduce variability) and then pooled. They were stored under dry conditions at room temperature until used for experiments.

\subsection{Microwave system}

An AMW200 batch microwave system (SAIREM SAS, Neyron, France) was used in this study. The $304 \mathrm{~L}$ microwave stainless steel chamber can contain a block of $0.6 \mathrm{~m} \times 0.4 \mathrm{~m}$ $\times 0.25 \mathrm{~m}$ maximum size and $30 \mathrm{~kg}$ maximum weight. The microwave system has a polyethylene sliding table with a usable surface of $0.84 \mathrm{~m} \times 0.62 \mathrm{~m}$ and a pneumatically driven sliding door, both making block loading/unloading easier. The microwave system operates at $915 \mathrm{MHz}$, which allows greater penetration and treatment of thicker materials (up to $0.25 \mathrm{~m}$ )

118 than the frequently used $2450 \mathrm{MHz}$ microwave frequency (approximately a threefold increase).

119 Coupling microwave heating from above and below and rotating the turntable enhance 120 heating homogeneity. The output power of $10 \mathrm{~kW}$ maximum is produced by $2 \times 5 \mathrm{~kW}$ 121 generators (magnetron), adjustable from $1 \mathrm{~kW}$ to $10 \mathrm{~kW}$. The system is water-cooled.

\subsection{Experimental design}

We applied three microwave treatments using the following power and duration pairings: $2 \mathrm{~kW} 4 \mathrm{~min}, 2 \mathrm{~kW} 8 \mathrm{~min}$ and $4 \mathrm{~kW} 4 \mathrm{~min}$. The effectiveness of these treatments was tested in

125 previous experiments (De Wilde et al., 2017; Hess et al., 2018). Microwave treatments were 126 performed on the premises of SAIREM (Neyron, France), each treatment being applied on 
$1271 \mathrm{~kg}$ soil replicates placed in $0.22 \mathrm{~m}$ high $\times 0.09 \mathrm{~m}$ diameter glass cylinders. Because the 128 presence of water in soil is essential to creating heat by microwave exposure (Metaxas and 129 Meredith, 1988), soil samples were not dried before compaction. Bulk density (i.e. mass of 130 dry soil / volume of bulk soil), which is a common measure of compaction, could therefore 131 not be calculated. Soil humidity before treatment was $7.3 \% \pm 1.2$ (mean $\pm \mathrm{SD})$.

For each microwave treatment, two compaction levels were tested: 'plain soil' 133 consisted of $1 \mathrm{~kg}$ soil filling a volume of $725 \pm 19 \mathrm{~cm}^{3}$ and 'compacted soil' consisted of soil 134 compacted directly in the cylinder using a metal weight until soil height was reduced by 135 $15 \pm 2 \%\left(616 \pm 15 \mathrm{~cm}^{3}\right)$ compared with plain soil. For each treatment (microwave treatment $\times$ compaction level), we used six replicates of soil containing (1) only the natural seed bank, (2)

137 ten seeds of each tested invasive species. Controls without microwave treatment were 138 replicates of plain soil containing (1) only the natural seed bank, and (2) ten seeds of each 139 tested invasive species. After microwave treatments, soil temperature was immediately 140 measured in each replicate, using mercury thermometers inserted in the center and at the 141 periphery of the cylinder ( $2 \mathrm{~cm}$ below soil surface). Before treatment, soil temperature was $14218.6 \pm 0.6^{\circ} \mathrm{C}$ (mean $\left.\pm \mathrm{SD}\right)$. After treatment, compacted soil samples were decompacted and all 143 samples (control and treated soil) were stored for 10 days at $30^{\circ} \mathrm{C}$. $19 \mathrm{~cm}$ diameter perforated plastic saucer containing from bottom to top: (1) a $21 \mathrm{~cm}$ diameter 146 Diatex filter (500-600 $\mu \mathrm{m}$ mesh size to prevent loss of coarse sand), (2) $1.5 \mathrm{~cm}$ of sterilized and 147 desalted sand and (3) a $23 \mathrm{~cm}$ diameter Diatex filter $(50-70 \mu \mathrm{m}$ mesh size to avoid loss of silt 148 and seeds). The plastic saucers were randomly placed in containers where a $1 \mathrm{~cm}$ water layer 149 was constantly adjusted so as to maintain soil moisture at a level conducive to germination 150 and prevent submersion. The experiment was conducted in an outdoor, pollen-free 151 greenhouse reducing the risk of granivory and contamination by seeds coming from the 
152 outside (Institute Tour du Valat, Arles, France). Seedling emergences were recorded weekly

153 for 6 weeks from June 23 to July 28, 2016. Identified individuals were regularly removed to

154 reduce competition.

155

156

157

158

159

160

161

162

163

164

165

166

167

168

\subsection{Statistical Analyses.}

We analyzed variations in soil temperature depending on the explanatory variable 'microwave treatment' ('control': absence of microwave treatment and three power and duration microwave treatment pairings: '2kW4min', '2kW8min' and '4kW4min') crosschecked against the explanatory variables 'compaction level' ('plain' or 'compacted) and 'measurement position' ('center' or 'periphery), using permutation tests. The p-values for the multiple comparison tests were adjusted with the $\mathrm{BH}$ adjustment (Benjamini and Hochberg, 1995). The tests were performed using the 'coin' R package (Hothorn et al., 2008; R Core Team, 2015).

We analyzed variations in the number of seedling emergences of monocotyledons and dicotyledons (seed bank) depending on the explanatory variable 'microwave treatment' in interaction with 'compaction level' using generalized linear models (GLM) with Poisson error distribution (Crawley, 2007). Tests were performed with function 'glm' in R (R Core Team, 2015). We also analyzed variations in the percentage of seedling emergences of Datura stramonium, Reynoutria $\times$ bohemica and Solidago gigantea depending on the explanatory variable 'microwave treatment' cross-checked against the variable 'compaction level' using Kruskal-Wallis or Wilcoxon rank sum tests.

All statistical tests were performed using R.3.3.2 software (R Core Team, 2015). P-values lower than 0.05 were considered as statistically significant.

\section{Results and discussion}


The three tested microwave treatments significantly raised soil temperature (close to

$17690^{\circ} \mathrm{C}$ in the $2 \mathrm{~kW} 8 \mathrm{~min}$ and $4 \mathrm{~kW} 4 \mathrm{~min}$ treatments and above $60^{\circ} \mathrm{C}$ in the $2 \mathrm{~kW} 4 \mathrm{~min}$ treatment;

177 Figure 1) and decreased seedling emergence of species from the seed bank and the invasive

178 species tested (Figure 2 and 3; $<<0.05$ ). These results are consistent with the notion that soil

179 microwave treatment affects seed viability via heat diffusion from surrounding soil (Barker

180 and Craker, 1991; Nelson, 1996). The 2kW4min treatment led to a ca. $50 \%$ decrease in

181 seedling emergence from the seed bank (Figure 2a,b) and an absence of differences in seedling emergence of $D$. stramonium and $R . \times$ bohemica compared with the control, which is consistent with previous studies (Figure 3a,b; De Wilde et al. 2017). This low effectiveness may have been reinforced by the $20^{\circ} \mathrm{C}$ soil temperature differences occurring between the center and the periphery of the cylinder (Figure 1). Indeed, microwave heating commonly results in uneven temperature distribution patterns (Brodie, 2008; Vadivambal and Jayas, 2010), with more intensive heating around the central axis and evaporative cooling at the surface of a small cylinder (Remmen et al., 1996; Hess et al., 2018). Seeds located at the periphery may have therefore been exposed to substantially lower temperature, which could explain the low effectiveness of the treatment as well as the high variability between 191 replicates.

Seeds of S. gigantea, however, appeared vulnerable to soil microwave heating, with seedling emergence reducing almost five-fold in the $2 \mathrm{~kW} 4 \mathrm{~min}$ treatment (plain soil) compared with the control (Figure 3c). This sensitivity, already revealed in previous experiments (De Wilde et al., 2017; Hess et al., 2018), could be linked to S. gigantea's small 196 seed size (Diprose et al., 1984). Testing the influence of seed size on a higher number of 197 samples and species, but also on seeds from one species having different sizes, would be useful to assess the role of seed size in the sensitivity to microwave heating. The thickness of seeds tegument, dormancy type, or the nature of seed reserves could also be impacting. 
201 homogeneous soil temperatures within the cylinders than the $2 \mathrm{~kW} 4 \mathrm{~min}$ treatment (Figure 1), and induced temperatures superior to $90^{\circ} \mathrm{C}$, considered as lethal for many types of seeds 203 (>80 ${ }^{\circ} \mathrm{C}$ during 30s; Barker and Craker, 1991), whatever soil compaction level. This enhanced 204 temperature homogeneity could be due to the increased exposure time or, more likely, output 205 power, resulting in changes in temperature spatial distribution by thermal diffusion from the zones where the microwave energy is being absorbed to the rest of the sample (Brodie, 2011). These more intensive treatments led to the total inhibition of invasive species seedling emergence (Figure 3) and a drastic decrease in seed bank seedling emergence (Figure 2). With the 2kW8min treatment, seedling emergence still occurred in the seed bank for both 210 levels of soil compaction but was reduced by $97 \%$ on average (Figure 1). Microwave heating 211 induces a rapid dehydration of plant tissues, causing plant death in few seconds of microwave treatment (Brodie et al., 2011). Above-ground and belowground plant tissues would therefore

213 be easily destroyed by microwave treatments used to control seedling emergence, but their 214 sensitivity will need to be assessed.

216 the $2 \mathrm{~kW} 4 \mathrm{~min}$ treatment, the number of seedling emergences of dicotyledons was significantly 217 reduced when soil was compacted (Figure 2 b). Furthermore, while some dicotyledons and $S$. 218 gigantea seedlings emerged in plain soil respectively in the $4 \mathrm{~kW} 4 \mathrm{~min}$ and $2 \mathrm{~kW} 4 \mathrm{~min}$ 219 treatments, no seedling emergence was observed in compacted soil for these treatments 220 (Figure 2b, 3c). The higher effectiveness observed in compacted soil is most probably due to 221 the higher bulk density and lower porosity obtained when compacting soil, resulting in higher 222 thermal conductivity during microwave treatment (Abu-Hamdeh, 2000; Yadav and Saxena, 223 1973). Such assumption corroborate with our results, showing that soil compaction tended to 224 increase soil temperature (Figure 1). 
Our results suggest that soil compaction, at the level tested in our experiment, does not

226 diminish but rather enhances the effectiveness of the microwave-based process (i.e. inhibition

227 of seedling emergence). This implies that microwave heating will be effective at reducing

228 unwanted species emergence in compacted soil, prevalent in agricultural areas (Drewry et al.

229 2008). However, deliberately compacting soil to enhance microwave effectiveness may be

230 detrimental to crop germination, growth, and water infiltration (Bassett et al., 2005; Benvenuti

231 and Mazzoncini, 2019; Skinner et al., 2009), so that soil might have to be decompacted before

232 sowing. These results also point out that soil compaction should be considered in the design

233 of the final microwave-based process: adjusting power and duration pairings to soil

234 compaction level may help saving energy or increasing treatment effectiveness.

\section{Acknowledgments}

We thank Dr. Mélissa De Wilde and Loïc Willm for their contribution to the 237 experimental phases of the study. This work is part of an FUI (French Inter-Ministerial R\&D

238 Fund) research and development project, co-financed by BPI France, Provence Alpes Côte d'Azur (PACA) and Occitanie/Pyrénées Mediterranée Regions and the Ain local authority. In

240 addition to the authors, the participants in this project also include scientists from the 241 companies GECO Ingénierie et Travaux, EDF, NGE-Guintoli, SAIREM and from the 242 laboratory ST\&M. No conflicts of interest have been declared. We thank Marjorie Sweetko 243 for reviewing the English of the paper. 


\section{References}

246 Abu-Hamdeh, N.H., Reeder, R.C., 2000. Soil thermal conductivity effects of density, moisture, salt concentration, and organic matter. Soil Sci. Soc. Am. J. 64, 1285-1290. https://doi.org/10.2136/sssaj2000.6441285x

Adair, R.J., 2005. The biology of Dasineura dielsi Rübsaamen (Diptera: Cecidomyiidae) in relation to the biological control of Acacia cyclops (Mimosaceae) in South Africa. Austral $\quad$ Entomol. 44, 446-456. https://doi.org/10.1111/j.14406055.2005.00487.x

Barker, A.V., Craker, L.E., 1991. Inhibition of weed seed germination by microwaves. Agron. J. 83, 302-305. https://doi.org/ 10.2134/agronj1991.00021962008300020008x

Baskin, J.M., Nan, X., Baskin, C.C., 1998. A comparative study of seed dormancy and germination in an annual and a perennial species of Senna (Fabaceae). Seed Sci. Res. 8, 501-512. https://doi.org/10.1017/S0960258500004475

Bassett, I.E., Simcock, R.C., Mitchell N.D., 2005. Consequences of soil compaction for seedling establishment: implications for natural regeneration and restoration. Austral Ecol. 30, 827-33. https://doi.org/10.1111/j.1442-9993.2005.01525.x

Bebawi, F.F., Cooper, A.P., Brodie, G.I., Madigan, B.A., Vitelli, J.S., Worsley, K.J. et al., 2007. Effect of microwave radiation on seed mortality of rubber vine (Cryptostegia grandiflora R. Br.), parthenium (Parthenium hysterophorous L.) and bellyache bush (Jatrophagos sypiifolia L.). Plant Protection Quarterly 22, 136.

Benjamini, Y., Hochberg, Y., 1995. Controlling the false discovery rate: a practical and powerful approach to multiple testing. J. R. Stat. Soc. : Series B Methodological 57, 

289-300. https://doi.org/10.1111/j.2517-6161.1995.tb02031.xBenvenuti, S., Macchia, M., 1997. Light environment, phytochrome and germination of Datura stramonium L. seeds. Environ. Exp. Bot. 38, 61-71. https://doi.org/10.1016/S0098-8472(96)01049-0

Benvenuti, S., Mazzoncini, M., 2019. Soil Physics Involvement in the Germination Ecology of Buried Weed Seeds. Plants 8, 7. https://doi.org/10.3390/plants8010007

Bochenek, A., Synowiec, A., Kondrat, B., Szymczak, M., Lahuta, L. B., Gołaszewski, J., 2016. Do the seeds of Solidago gigantea Aiton have physiological determinants of invasiveness?. Acta Physiol. Plant. 38, 159. https://doi.org/10.1007/s11738-016-2179-6

Brodie, G., 2011. Microwave heating in moist materials, in: Grundas, S., (Eds.), Advances in Induction and Microwave Heating of Mineral and Organic Materials, InTech, Vienna, pp. 553-584.

Brodie, G., Ryan, C., Lancaster, C., 2011. Microwave technologies as part of an integrated weed management strategy: A review. International Journal of Agronomy 2012. https://doi.org/10.1155/2012/636905

Campbell, P.L., Naudé, D.C., Kluge, R.L., 1999. Development of integrated control strategies for wattle. II. Control of unwanted wattle. South African Journal of Plant and Soil 16, 31-37. https://doi.org/10.1080/02571862.1999.10634842

Cohen, O., Gamliel, A., Katan, J., Kurzbaum, E., Riov, J., Bar, P., 2018. Controlling the seed bank of the invasive plant Acacia saligna: comparison of the efficacy of prescribed 
burning, soil solarization, and their combination. Biol. Inv. 20, 2875-2887. https://doi.org/10.1007/s10530-018-1738-8

290 Cohen, O., Riov, J., Katan, J., Gamliel, A., Bar, P., 2008. Reducing persistent seedbanks of invasive plants by soil solarization - the case of Acacia saligna. Weed Sci. 56, 860-865.

292 https://doi.org/10.1614/WS-08-073.1

293 Cohen, O., Rubin, B., 2007. Soil solarization and weed management, in: Upadhyaya and Blackshaw (Eds.), Non-chemical weed management: principles, concepts and technology, CABI publishing, Wallingford, pp. 155-175.

296

297

298

299

300

301

302

303

304

305

306

Christoffoleti, P.J., De Carvalho, S.J.P., López-Ovejero, R.F., Nicolai, M., Hidalgo, E., Da Silva, J.E., 2007. Conservation of natural resources in Brazilian agriculture: implications on weed biology and management. Crop. Prot. 26, 383-389. https://doi.org/10.1016/j.cropro.2005.06.013

Crawley, M.J., 2007. Generalized linear models, in: John Wiley \& Sons (Eds.) R book. Wiley \& Sons, Chichester, pp. 511-526.

Davis, F.S., Wayland, J.R., Merkle, M.G., 1971. Ultrahighfrequency electromagnetic fields for weed control: Phytotoxicity and selectivity. Science 173, 535-537. https://doi.org/10.1126/science.173.3996.535

Davis, F.S., Wayland, J.R., Merkle, M.G., 1973. Phytotoxicity of a UHF field. Nature 241, 291-292. https://doi.org/10.1038/241291a0

307 De Vries, D.A., 1952. Thermal conductivity of soil. Meded. Landbouwhogesch,Wageningen, the Netherlands. 
De Wilde, M., Buisson, E., Yavercovski, N., Willm, L., Bieder, L., Mesléard, F., 2017. Using microwave soil heating to inhibit invasive species seed germination. Invas. Plant Sci. Mana. 10, 42-51. https://doi.org/10.1017/inp.2017.29

312

313

314

315

316

Diprose, M.F., Benson, F.A., Willis, A.J., 1984. The effect of externally applied electrostatic fields, microwave radiation and electric currents on plants and other organisms, with special reference to weed control. Bot. Rev. 50, 171-223. https://doi.org/10.1007/BF02861092

Gillies, S., Clements, D.R., Grenz, J., 2016. Knotweed (Fallopia spp.) invasion of North America utilizes hybridization, epigenetics, seed dispersal (unexpectedly), and an arsenal of physiological tactics. Invas. Plant Sci. Mana. 9, 71-80. https://doi.org/10.1614/IPSM-D-15-00039.1

Drewry, J.J., Cameron, K.C., Buchan, D., 2008. Pasture yield and soil physical property responses to soil compaction from treading and grazing - a review. Aust. J. Soil Res. 46, 237-56. https://doi.org/10.1071/SR07125

Engler, J., Abt, K., Buhk, C., 2011. Seed characteristics and germination limitations in the highly invasive Fallopia japonica sl (Polygonaceae). Ecol. Res. 26, 555-562. https://doi.org/10.1007/s11284-011-0813-8

Herranz, J.M., Ferrandis, P., Martínez-Sánchez, J.J., 1998. Influence of heat on seed germination of seven Mediterranean Leguminosae species. Plant Ecol. 136, 95-103. https://doi.org/10.1023/A:1009702318641

Hess, M.C.M., De Wilde, M., Yavercovski, N., Willm, L., Mesléard, F., Buisson, E., 2018. Microwave soil heating reduces seedling emergence of a wide range of species including invasives. Restor. Ecol. 26, S160-S169. https://doi.org/10.1111/rec.12668 
Holmes, P.M., 1989. Effects of different clearing treatments on the seed-bank dynamics of an invasive Australian shrub, Acacia cyclops, in the southwestern Cape, South Africa. Forest Ecol. Manag. 28, 33-46. https://doi.org/10.1016/0378-1127(89)90072-8

Hothorn, T., Hornik, K., Van de Wiel, M.A., Zeileis, A. 2008. Implementing a class of permutation tests: the coin package. J. Stat. Softw. 28, 1-23

Impson, F.A.C., Moran, V.C., Hoffmann, J.H., 2004. Biological control of an alien tree, Acacia cyclops, in South Africa: impact and dispersal of a seed-feeding weevil, Melanterius servulus. Biol. control 29, 375-381. https://doi.org/10.1016/S10499644(03)00159-2

Katan, J., Shtienberg, D., Gamliel, A., 2012. The integrated management concept in the context of soilborne pathogens and soil disinfestation, in: Gamliel, A., Katan, J. (Eds.), Soil solarization: theory and practice, APS Press, Minesota, pp. 91-98.

Kleunen, M.V., Fischer, M., Johnson, S.D., 2007. Reproductive assurance through selffertilization does not vary with population size in the alien invasive plant Datura stramonium. Oikos 116, 1400-1412. https://doi.org/10.1111/j.0030-1299.2007.16004.x

Loddo, D., Sousa, E., Masin, R., Calha, I., Zanin, G., Fernández-Quintanilla, C., Dorado, J., 2013. Estimation and comparison of base temperatures for germination of European populations of velvetleaf (Abutilon theophrasti) and jimsonweed (Datura stramonium). Weed Sci. 61, 443-451. https://doi.org/10.1614/WS-D-12-00162.1

Metaxas, A.A., Meredith, R.J., 1988. Industrial microwave heating, IEE Power Engineering Series 4, London. 
Myers, J.H., Savoie, A., Van Randen, E. 1998. Eradication and pest management. Annu. Rev. Entomol. 43, 471-491. https://doi.org/10.1146/annurev.ento.43.1.471

R Core Team, 2015. R A language and environment for statistical computing. R Foundation for Statistical Computing. http://www.R-project.org/ (accessed 6 August 2016).

Regan, T.J., McCarthy, M.A., Baxter, P.W.J., Panetta, F.D., Possingham, H.P., 2006. Optimal eradication: when to stop looking for an invasive plant. Ecol. Lett. 9, 759-766. https://doi.org/10.1111/j.1461-0248.2006.00920.x

Remmen, H.H., Ponne, C.T., Nijhuis, H.H., Bartels, P.V., Kerkhof, P.J., 1996. Microwave heating distributions in slabs, spheres and cylinders with relation to food processing. J. Food. Sc. 61, 1105-1114. https://doi.org/10.1111/j.1365-2621.1996.tb10941.x

Richardson, D.M., Kluge, R.L., 2008. Seed banks of invasive Australian Acacia species in South Africa: role in invasiveness and options for management. Perspect. Plant Ecol. 10, 161-177. https://doi.org/10.1016/j.ppees.2008.03.001

Saayman, A.E.J., 2000. Influence of intraspecific competition on seed production of Datura stramonium L.. South African Journal of Plant and Soil 17, 70-73. https://doi.org/10.1080/02571862.2000.10634871

Sahin, H., 2014. Effects of microwaves on the germination of weed seeds. Journal of Biosystems Engineering 39, 304-309. https://doi.org/10.5307/JBE.2014.39.4.304

Saito, T.I., Tsuyuzaki, S., 2012. Response of riparian vegetation to the removal of the invasive forb, Solidago gigantea, and its litter layer. Weed Biol. Manag. 12, 63-70. https://doi.org/10.1111/j.1445-6664.2012.00436.x 
374 Sartorato, I., Zanin, G., Baldoin, C., Zanche, C., 2006. Observations on the potential of microwaves for weed control. Weed Res. 46, 1-9. https://doi.org/10.1111/j.13653180.2006.00484.x

Skinner, A.K., Lunt, I.D., Spooner, P., McIntyre, S.U.E., 2009. The effect of soil compaction on germination and early growth of Eucalyptus albens and an exotic annual grass. Austral Ecol, 34: 698-704. https://doi.org/10.1111/j.1442-9993.2009.01977.x

Strong, D.R., Pemberton, R.W., 2000. Biological control of invading species-risk and reform. Science 288, 1969-1970. https://doi.org/10.1126/science.288.5473.1969

Thompson, A.J., Jones, N.E., Blair, A.M., 1997. The effect of temperature on viability of imbibed weed seeds. Ann. Appl. Biol. 130, 123-134. https://doi.org/10.1111/j.17447348.1997.tb05788.x

Tieu, A., Dixon, K. W., Meney, K. A., Sivasithamparam, K., 2001. The interaction of heat and smoke in the release of seed dormancy in seven species from southwestern Western Australia. Ann. Bot-London 88, 259-265. https://doi.org/10.1006/anbo.2001.1451

Vadivambal, R., Jayas, D.S., 2010. Non-uniform temperature distribution during microwave heating of food materials-A review. Food and Bioprocess Technology 3, 161-171. https://doi.org/10.1007/s11947-008-0136-0

Weber, E., 2017. Invasive plant species of the world: a reference guide to environmental weeds, second ed. CABI international publishing, Oxfordshire.

Weber, E., Jakobs, G., 2004. Biological flora of central Europe: Solidago gigantea Aiton. Flora 200, 109-118. https://doi.org/10.1016/j.flora.2004.09.001 
395 Yadav, M.R., Saxena, G.S., 1973. Effect of compaction and moisture content on specific heat 396 and thermal capacity of soils. Journal of the Indian Society of Soil Science 21, 129-132.

397 Zimmermann, H.G., Moran, V.C., Hoffmann, J.H., 2004. Biological control in the 398 management of invasive alien plants in South Africa, and the role of the Working for

399 Water Programme: working for water. S. Afr. J. Sci. 100, 34-40.

400 

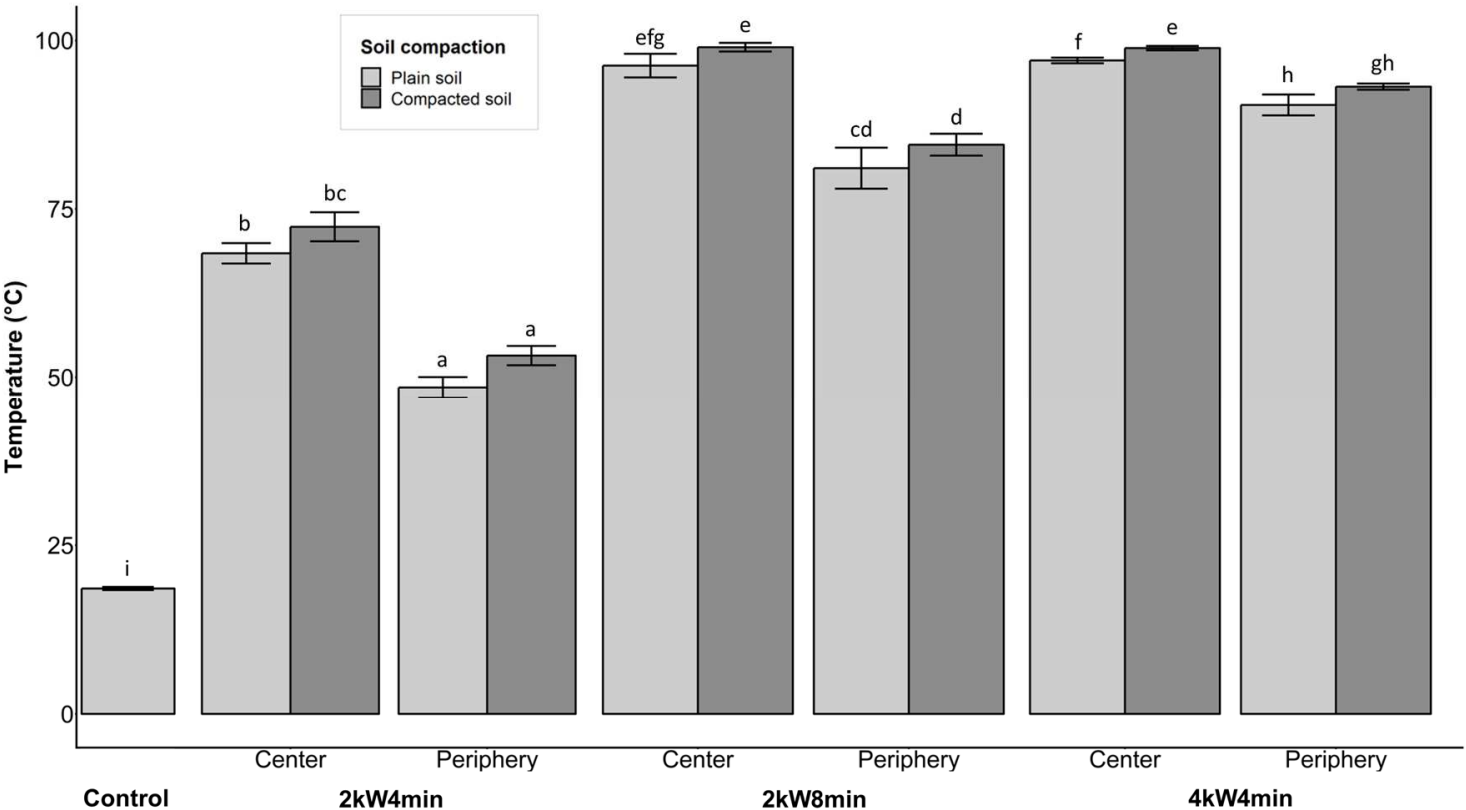

403 Figure 1. Effect of microwave treatment (control: without microwave treatment and three

404 pairings of power and duration: $2 \mathrm{~kW} 4 \mathrm{~min}, 2 \mathrm{~kW} 8 \mathrm{~min} 4 \mathrm{~kW} 4 \mathrm{~min}$ ), position in the cylinder 405 ('center' or 'periphery') and soil compaction level ('plain' or 'compacted') on soil 406 temperature $\left({ }^{\circ} \mathrm{C}\right)$. Values are expressed as means $\pm \mathrm{SE}$ of the six replicates. Letters

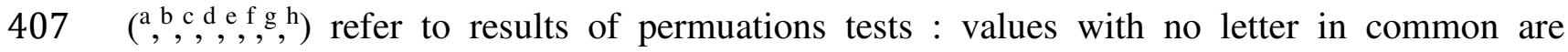
408 significantly different (multiple comparison tests adjusted with the $\mathrm{BH}$ adjustment; $\mathrm{p}<0.05$ ). 
(a) Monocotyledons

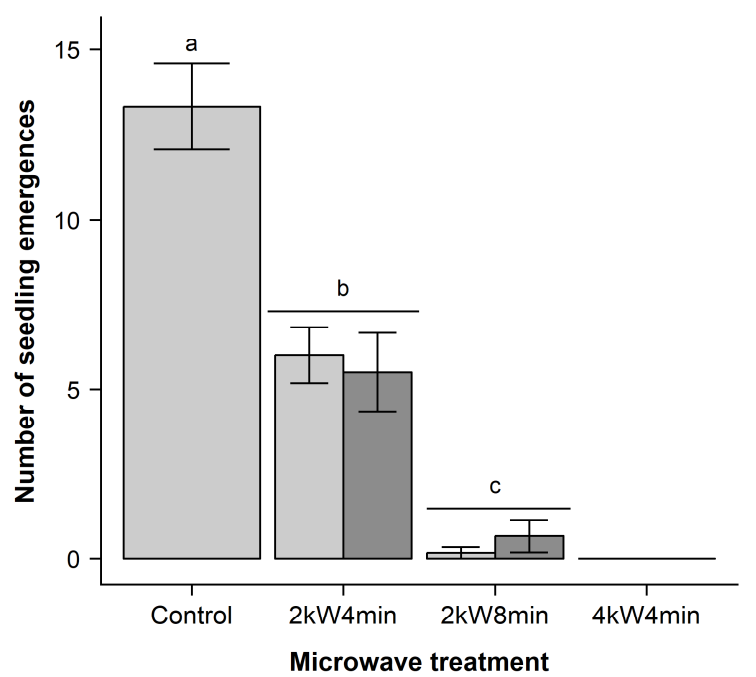

(b) Dicotyledons

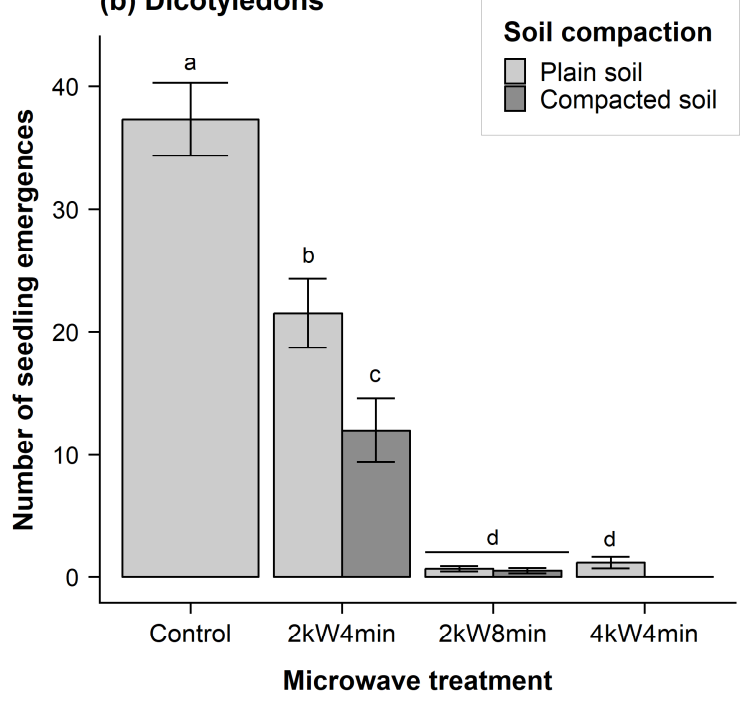

410

411 Figure 2. Effect of microwave treatment (control: without microwave treatment and three

412 pairings of power and duration: $2 \mathrm{~kW} 4 \mathrm{~min}, 2 \mathrm{~kW} 8 \mathrm{~min} 4 \mathrm{~kW} 4 \mathrm{~min}$ ) and soil compaction level

413 ('plain' or 'compacted') on the number of seedling emergences of the seeds bank including

414 (a) monocotyledons and (b) dicotyledons. Values are expressed as means \pm SE of the six

415 replicates. Letters $\left({ }^{a},{ }^{b},{ }^{c}\right)$ ) refer to results of post-hoc Tukey's tests : values with no letter in

416 common are significantly different $(\mathrm{p}<0.05)$. 
(a) Datura stramonium

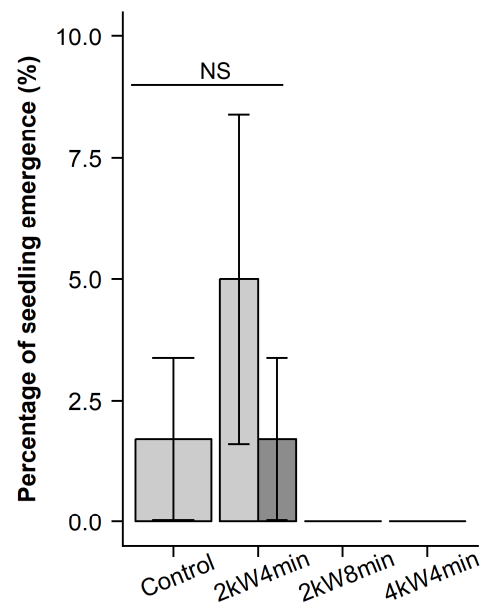

Microwave treatment (b) Reynoutria × bohemica

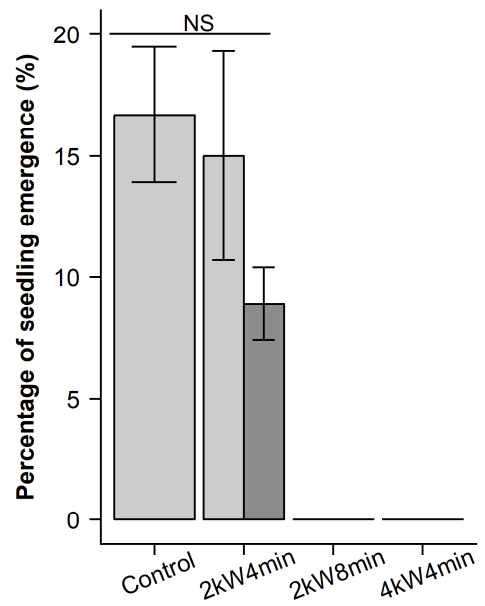

Microwave treatment (c) Solidago gigantea

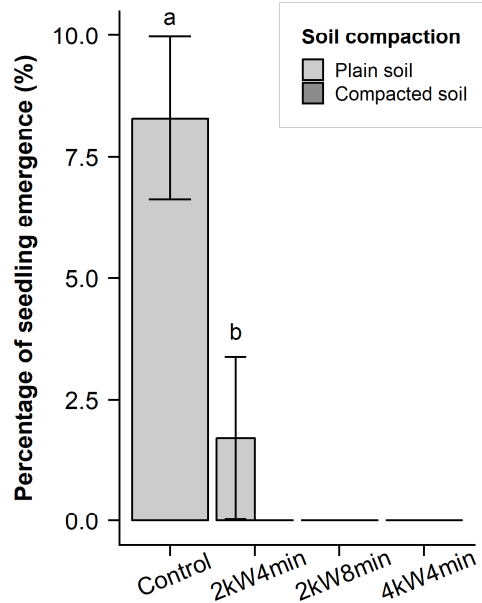

Microwave treatment

Figure 3. Effect of microwave treatment (control: without microwave treatment and three

421 pairings of power and duration: $2 \mathrm{~kW} 4 \mathrm{~min}, 2 \mathrm{~kW} 8 \mathrm{~min} 4 \mathrm{~kW} 4 \mathrm{~min}$ ) and soil compaction level

422 ('plain' or 'compacted') on the percentage of seedling emergences of (a) Datura stramonium

423 (b) Reynoutria $\times$ bohemica and (c) Solidago gigantea. Values are expressed as means \pm SE of

424 the six replicates. Letters $\left({ }^{a},{ }^{b}\right)$ refer to the result of a Wilcoxon test : values with no letter in

425 common are significantly different $(\mathrm{p}<0.05)$. NS means "non-significant", when no statistical

426 difference was found $(\mathrm{p}<0.05)$. 